Dorota Fortuna

Warszawa

\title{
„Kłosy” o książce i prasie w Galicji (1865-1890)
}

W drugiej połowie XIX wieku na ziemiach polskich słowo drukowane miało szczególne znaczenie. Prasa spełniała ważną funkcję informacyjną, ale miała też ogromne znaczenie społeczne jako element integracji narodu. Stała się wręcz enklawą polskości.

Niniejsza praca ${ }^{1}$ jest próbą spojrzenia na problemy polskiego ruchu wydawniczego $\mathrm{w}$ drugiej połowie XIX wieku $\mathrm{z}$ perspektywy informacji zawartych $\mathrm{w}$ tygodniku ilustrowanym „Kłosy”, który ukazywal się w latach 1865-1890. Redakcja "Klosów” miała ambicje prezentowania szerokiego spojrzenia na życie społeczne i kulturalne, sprawy polityczne pozostawiając dziennikom. W felietonach oraz korespondencjach nadsyłanych $\mathrm{z}$ różnych części kraju poruszano problematykę ruchu naukowego, literackiego, wydarzeń kulturalnych oraz poddawano ocenom bieżące wydawnictwa. Z tego powodu „Klosy” są cennym źródłem informacji o stanie polskiego ruchu wydawniczego w tym okresie ${ }^{2}$. Wiele ciekawych informacji na ten temat wniosła analiza rubryk programowo zajmujących się ruchem literackim i wydawniczym³.

„Kłosy" wydawane były w Warszawie, ale docierały daleko poza teren Królestwa Polskiego. Podkreślając często swój ogólnonarodowy charakter zamieszczały artykuły dotyczące ziem polskich, niezależnie od ich przynależności zaborowej. Dużo miejsca na swych łamach poświęcały między innymi wydawnictwom galicyjskim.

${ }^{1}$ Artykuł ten jest częścią pracy magisterskiej przygotowanej pod kierunkiem prof. dr. hab. Jana Dziegielewskiego i dr hab. Anny Kamler w Instytucie Informacji Naukowej i Studiów Bibliologicznych UW w $2008 \mathrm{r}$.

${ }^{2}$ Ze względu na pokaźną objętość czasopisma, dokładnej analizie poddano wybrane roczniki. Uwzględniono lata: 1865-1866 (jako początkowe dla istnienia „Kłosów”), 1870 (jako pierwszy rok, który przyniósł wydawcy „Kłosów” zyski), 1880 (jako kończący dobrą koniunkturę „Klosów”, tuż przed ponownym zaostrzeniem cenzury carskiej i nasileniem rusyfikacji) oraz 1889-1890 (zamykające pismo). Ze względu na jubileusz dwudziestolecia obchodzony przez to czasopismo w 1884 roku, rocznik ten został również uwzględniony.

${ }^{3}$ Podstawą wniosków stały się rubryki: Przeglq̨d piśmiennictwa polskiego; Kronika lwowska literacka i naskowa; Kronika powszechna - Bibliografia i przegląd pism; Wiadomości bież̨ce z pola nauki, literatury i sztuki - Literatura: Bibliografia; Nowe ksiażki nadestane oraz Korespondencje. Dodatkowym żródłem informacji o wydarzeniach lwowskich czy krakowskich było Pokłosie oraz artykuły poświęcone konkretnym zagadnieniom (np. Kartka z dziejów oświaty ludowej w Galicyi czy Literatura ludowa). 


\section{Sytuacja społeczno-polityczna w Galicji}

Aby zrozumieć specyfikę galicyjskich wydawnictw należy poznać warunki polityczne, gospodarcze i społeczne, panujące wówczas na tym terenie. Od kiedy w 1861 roku państwo Habsburgów zaczęło przekszalacać się w federację autonomicznych krajów, nastały też lepsze czasy dla Galicji i Lodomerii, ziem polskich podlegających zaborcy austriackiemu. Proces ten trwał kilkanaście lat ${ }^{4}$. Jego kulminacja nastapila w 1867 roku, kiedy to powstała monarchia austro-węgierska. Galicja znalazła się wówczas w części austriackiej. Pierwsze oznaki złagodzenia germanizacji pojawily się już w roku 1860 . Wprowadzono wówczas język polski (obok niemieckiego) do urzędów i sądów. W 1861 roku zebral się pierwszy galicyjski Sejm Krajowy. Od 1867 roku można było nauczać języka polskiego w szkołach. W 1869 roku rozporządzenie cesarza wprowadzilo język polski do administracji, policji i sądownictwa a konstytucja austriacka zagwarantowała prawa i wolności obywatelskie.

Mimo pozornie sprzyjających warunków Galicja borykała się z wieloma problemami. Rozwój samorządów, które w miastach pracowały na rzecz poprawy jakości zycia, w ośrodkach gminnych był silnie ograniczany przez wysoki procent analfabetyzmu (ok. 80\%) ${ }^{5}$. Brakowało ludzi przygotowanych do pełnienia funkcji samorządowych. Na pelne wykorzystanie autonomii nie pozwalał też niski poziom cywilizacyjny. W stosunku do rozwoju przemysłu i rolnictwa europejskiego Galicja pozostawała mocno zapóźniona. Przez lata rozwój ekonomiczny hamowały polskie elity rządzące oraz austriacka polityka celna. Ziemie Galicji były typowo rolnicze. W 1869 roku ludność wiejska stanowiła 87\% ogółu mieszkańców ${ }^{6}$. W związku z tym intensywnie rozwijał się tu ruch ludowy. Działalność oświatową podejmowały zarówno jednostki (ks. Stanisław Stojałowski, Maria i Bolesław Wysłouchowie) ${ }^{7}$, jak i organizacje społeczne (Towarzystwo Oświaty Ludowej we Lwowie oraz Macierz Polska,).

Szkolnictwo podstawowe i gimnazjalne rozwijało się bardzo słabo aż do początku lat dziewięćdziesiątych, kiedy to można zaobserwować nieznaczną poprawę. Dobrze natomiast działały spolszczone w latach siedemdziesiątych wyższe uczelnie. Oba uniwersytety - krakowski i lwowski, skupiały znakomitości polskiej i europejskiej nauki ${ }^{8}$. Funkcje naukowe w Krakowie pełniła Akademia Umiejętności (1872) oraz Muzeum Narodowe (1879). We Lwowie warsztatem naukowym stał się Zakład Narodowy im. Ossolińskich. W obu ośrodkach działały polskie teatry a miasta galicyjskie stały się miejscem organizowania rocznicowych i jubileuszowych uroczystości narodowych.

\footnotetext{
${ }^{4}$ A. Chwalba, Historia Polski 1795-1918, Kraków 2000, s. 491.

5 Tamże, s. 503.

${ }^{6}$ Tamże, s. 505.

${ }^{7}$ Tamże, s. 519.

${ }^{8}$ Tamże, s. 514.
} 


\section{Lwów „stolica kraju"9 - lata szesćdziesiąte}

Lwów był w omawianym czasie stolicą kraju - Królestwa Galicji i Lodomerii - przez wspólczesnych nazywanym królestwem „golicji i głodomerii”. Mimo trudności ekonomicznych, na jakie napotykały wszelkie inicjatywy, w latach sześćdziesiątych ruch literacki i naukowy w Galicji powoli zaczął się odradzać.

W Kronice lwowskiej z 1865 roku podano wiadomość, że pan Turowski ${ }^{10}$ rozpocząl wydawanie przerwanej na trzy lata „Biblioteki polskiej”. Była to seria prac historycznych i społecznych. Wśród opublikowanych (przed zawieszeniem cyklu) znalazły się dzieła M. Reja, K. Brodzińskiego i P. Skargi. Wśród zapowiedzianych figurowały prace hr. Józefa Załuskiego, w tym Rzecz o konnym putku polskim Napoleona $I^{11}$. Dwa miesiące później w Kronice lwowskiej czytamy: ,Jednakże jakkolwiek rzeczy się mają, zawsze faktem jest, że na przykład w stosunku do Warszawy, Poznania, Lwów i Kraków pod względem ruchu umysłowego w tej chwili daleko za niemi pozostały"12.

Nie bez echa pozostał fakt przygotowania pośmiertnego wydania utworów Juliusza Słowackiego. Według Kroniki lwowskiej autorem i wykonawcą pomysłu byl profesor Antoni Małecki, „znawca pism” poety. Wartość poezji Słowackiego dopiero zaczęto doceniać: „Czytaliśmy kilka ustępów tych genialnych utworów; zaiste słowa Juliusza „do mnie należy przyszłość” spełnią się rzeczywiście, a palma przewodnictwa w poezji Adama, przechodzi w ręce tego olbrzymiego geniuszu"13. Kilka tygodni później znaleźć można już wiadomość o tym, iż profesor Malecki $z$ upoważnienia spadkobierców i krewnych ogłasza przedpłatę na te dzieła ${ }^{14}$. Pisma Słowackiego ukazały się we Lwowie w 1866 roku.

W rubryce Korespondencya czasopisma Ktosy autor podpisujący sie „Em.”"15 charakteryzuje ruch literacki i kulturalny oraz donosi o różnych sensacyjnych wydarzeniach, mających miejsce we Lwowie. Rok 1866 rozpoczyna optymistyczną wiadomością, iż „ruch literacki zaczyna się ożywiać" ${ }^{\prime 6}$. Na potwierdzenie swych słów wymienia nowości literackie a wśród nich prace dotyczące języka polskiego, jego gramatyki oraz prace literaturoznawcze: prelekcje o literaturze XIX wieku Wincentego Pola oraz „Historię literatury polskiej” autorstwa Felicji Wasilew-

${ }^{9}$ „Klosy”, 38:1884, nr 977, s. 181.

${ }^{10}$ Kazimierz Józef Turowski podjąl próbę popularyzacji literatury polskiej poprzez jej tanie wydania. W 1855 roku w Sanoku ogłosil prospekt, zapowiadający „Bibliotekę Polską”. Wydawał tę serię do 1861 roku, początkowo w Przemyślu, póżniej w Krakowie. Zob. M. Konopka, Tanie wydania literatury pięknej w Galicji $i$ Wolnym Mieście Krakowie w latach 1822-1863, Kraków 1987, s. 36.

${ }^{11}$ Kronika lwowska literacka i naukowa. „Klosy”, 1:1865, nr 9, s. 108.

${ }^{12}$ Kronika lwowska.... „Kłosy”, 1:1865, nr 19, s. 225.

${ }^{13}$ Kronika lwowska.... „Kłosy” 1:1865, nr 1, s.11.

${ }^{14}$ Em., Korespondencya czasopisma Ktosy, „Kłosy”, 1:1865, nr 9, s.108.

${ }^{15}$ Adam Bar, Stownik pseudonimów i kryptonimów, Kraków 1936, podaje trzy rozwiązania: dwa należy wykluczyć ze względu na lata życia osób podpisujących się w ten sposób. Pozostaje Stanislaw Milkiewicz, którego jednakże wśród wspólpracowników „Kłosów” nie odnotowano. W spisie znajduje się podobnie brzmiące nazwisko-Stanisław Miłkowski, ten jednakże używal kryptonimu S. M. (zob. A. Bar, Stownik..., t. 1, s. 111).

${ }_{16}$ Em., Korespondencya..., „Kłosy”, 2:1866, nr 27, s. 319. 
skiej. W grupie literatury pięknej wymienia tłumaczenia antycznych arcydzieł dramatycznych, których dokonuje "pisarz historyczny i poetyczno dramatyczny” Józef Szujski ${ }^{17}$. Nieco później pisze: „mogę wykazać, że życie naszego krajowego piśmiennictwa na nowo się rozbudza"18. Wymienia tytuły czasopism, które zaczęly się ukazywać w ostatnim czasie: „Dziennik Literacki”, „Tygodnik Naukowy”, „Łada” oraz pisma humorystyczne „Bąk” i „Chochlik”.

Em. analizując tematykę publikowanej literatury zauważa także zainteresowania historyczne. Jako przykład podaje informację, iż nakładem Seelmana Igla $^{19}$ ukazały się listy Władysława IV do Krzysztofa Radziwilla. Listy te miały niezwykłą wartość, ponieważ zostały opracowane na podstawie rękopisów $z$ Biblioteki Petersburskiej (ze wstępem J. I. Kraszewskiego). W tej samej rubryce znajduje się wiadomość o odnalezieniu w archiwach lwowskich i krakowskich dokumentacji $z$ procesu kanonizacyjnego św. Katarzyny z 1475 roku. Publikacja tych dokumentów miala być finansowana $z$ funduszy prywatnych, między innymi hr. Aleksandra Stadnickiego. Niestety okazaly się one zbyt "szczuple” i „sejm krajowy” postanowil „tak ważnemu wydawnictwu przyjść w pomoc z funduszami”20. Nie odnotowano w „Kłosach”, w jaki sposób sejm galicyjski to postanowienie zrealizowal.

W lutym 1870 roku i tak wątly ruch literacki we Lwowie zamarl calkowicie. Przyczyną tego stanu rzeczy okazał się być strajk zecerów, którzy odmówili pracy, żądając wyższych wynagrodzeń („według cenników paryskich”). Niestety zapomnieli oni o tym, że zainteresowanie kupnem dzieł literackich na ziemiach polskich jest dużo niższe niż za granicą - „w krajach przesiąkłych oświatą, w których nie ma nikogo prawie, coby się obchodzil bez dziennika lub ksiażki odpowiedniej" 21 .

Porównanie czytelnictwa galicyjskiego $z$ europejskim wypada więcej niż słabo. Jak napisal korespondent: „tam każdej książki lub dziennika rozchodzi się po

17 Talent J. Szujskiego jako pisarza jest porównywany przez korespondenta „Kłosów” do mistrzów romantycznych: Slowackiego, Mickiewicza i Krasińskiego. Zob. Kronika lwowska..., „Kłosy”, 1:1865, nr 19, s. 226

${ }^{18}$ Em., Korespondencya ..., „Kłosy”, 2:1866, nr 36, s. 431.

${ }^{19}$ Seelman Igel (1813-1870), znany również jako Salomon czy Zelman, był synem Dawida Igla, założyciela znanej lwowskiej dynastii antykwariuszy. Handlowal glównie starodrukami, pochodzacymi z likwidowanych na terenie zaboru rosyjskiego i austriackiego zakonów. We Lwowie nazywano go „antikwaryuszem z Rosji”. Bywal w Krzemieńcu, Łucku, Żytomierzu, Kamieńcu Podolskim. Przywoził książki do Lwowa dla księgarni Kajetana Jablonowskiego, był dostawca Ossolineum i nabywcą ksiajek z dubletów Zakładu Narodowego. W 1855 osiadl na stałe we Lwowie, gdzie jego antykwariat pełnił również rolę księgarni nakładowej. W tym okresie wydal wspomniane Listy Wtadystawa IV do Krzysztofa Radziwitla. W latach sześćdziesiątych wydawał „Bibliotekę teatralną lwowską", serię utworów dramatycznych M. Bałuckiego, A. Fredry, J. Korzeniowskiego. Zgodził się wydać pisma J. Supińskiego, dla którego trudno było znaleźć nakładcę. Po roku 1870 we Lwowie pojawilo się kilka nowych firm ksieggarskich. stanowiących silną konkurencję dla następców Seelmana. W 1889 roku następcy Igla otrzymali koncesję na prowadzenie antykwariatu w Krakowie. Zob. M. Opalek, Sto trzydzieści lat wśród ksiqzek, lwowscy antykwarze Iglowie, Lwów 1928, s. 10-25.

${ }^{20}$ Em., Korespondencya..., „Klosy", 2:1866, nr 27, s. 319.

${ }^{21}$ Korespondencya czasopisma Klosy, „Kłosy”, 10:1870, nr 243, s. 126. 
kilka lub kilkanaście, lub więcej tysięcy egzemplarzy. [...] U nas na całą Galicję co najwięcej rozchodzi się poczytnej książki około pięciuset egzemplarzy, a gazety malo więcej jak dwa razy tyle"22. Kondycja wydawców i drukarzy jest zaś na tyle słaba, że nie tylko nie zdobywają majątków, ale ich zyski są tak niskie, że „dzienniki bankrutują $z$ braku przedpłaty i upadają jedne po drugich, że książki stosami leżą na składach księgarskich nie znajdując należytego pokupu"z3. W obliczu takich warunków zecerzy nie mieli szans na osiagnięcie swoich celów. Drukarnie nie pracowaty przez dwa tygodnie. „Druk wszelkich książek zawieszono, podobnie jak i pism, a tylko codzienne wychodziły w zmniejszonym o połowę formacie, składane przez rozmaitych dyletantów..."24. W końcu właściciele drukarń poszli na niewielkie ustępstwa. $Z$ początkiem lutego 1870 roku praca w lwowskich drukarniach ruszyła - „i tak skończyl się niewidziany dotąd nigdy we Lwowie strike drukarski"25.

\section{"Książkowstręt galicyjski”26}

Kolejne lata nie były laskawsze dla galicyjskiej książki i prasy. Zainteresowanie czytelników było tak słabe, że nowe wydawnictwa prawie nie znajdowały nabywców. Korespondencja czasopisma Kłosy z Krakowa, z 1870 roku, jest bardzo pesymistyczna. Korespondent - Michał Bałucki pisze, że nie będzie mógl dotrzymać obietnicy i poświęcić swego tekstu ruchowi literackiemu, ponieważ ten ,jest tak mały, że równa się stagnacyi. [...] Wydawanie nowych książek jest, jak to dawniej powiedzialem, rodzajem poświęcenia, które może na tamtym świecie nakładcy za dobry uczynek policzonem będzie, ale na tym, a w szczególności w Galicyi, nie znajduje ani uznania, ani kupujących. Nowa ksiązka jest u nas rzadkością, na którą rzadko kto zwraca uwagę i nigdzie jej nie zobaczysz, chyba za wystawka księgarską"27. Dalej autor pisze jednak o kilku książkach, które znalazł na pólkach księgarskich. Wymienia wśród nich: herbarz Ignacego Kapicy Milewskiego, nieduży poemat Trzeciaka i „tomiki dla klas pracujących” Karola Forstera ${ }^{28}$.

Poszukując wartych zaprezentowania inicjatyw, korespondent wymienia serię wykładów w Muzeum techniczno-przemysłowym o literaturze i muzy-

${ }^{22}$ Tamże, s. 127.

${ }^{23}$ Tamże.

${ }^{24}$ Tamże.

${ }^{25}$ Tamże.

${ }^{26}$ Określenie pochodzi z podtytułu do Korespondencji z Krakowa w 1870 roku. Zob. Korespondencya czasopisma Klosy, „Kłosy”, 10:1870, nr 246, s. 168.

${ }^{27}$ Tamże.

${ }^{28}$ Chodzi prawdopodobnie o serie wydawnictw Karola Forstera zatytułowaną Klasom pracujacym polskim sześć ksiazieczek przynosi szczery ich przyjaciel Karol Forster, ukazującą się w latach 1867-1870, w czterech mniejszych seriach po „sześć książeczek” w każdej. Tomiki te wydawane były w Berlinie. Być może zostały uwzględnione w korespondencji krakowskiej jako dzielka do nabycia w miejscowych księgarniach. $Z$ tekstu zamieszczonego w „Kłosach" nie wynika jasno, o jakich „tomikach” mówi korespondent. 
ce, które także nie cieszą się zainteresowaniem. Publiczność bowiem z wielką obojętnością traktuje zarówno słowo pisane, jak i czytane, zaś „kupowanie książek uważa jeżeli nie za rodzaj zbytku, to za karę, której się tylko w ostateczności poddaje"29. Znajduje on jednak usprawiedliwienie dla tego stanu, ponieważ życie ludności galicyjskiej zdominowane jest przez „troskę o chleb powszedni” ${ }^{30}$. Jeśli chodzi o niższe warstwy społeczne to faktycznie jest to potrzeba utrzymania się przy życiu, natomiast klasy wyższe skupiają się na gromadzeniu majątków, które to zajęcie „stało się dziś alfą i omegą dażeń wielu ludzi”31.

W lutym 1880 roku, w korespondencji ze Lwowa, obok optymistycznych wiadomości o ukazujących się nowych tytulach czasopism, znalazła się informacja o słabej kondycji ekonomicznej wydawnictw już istniejących. "Kłosy” podały, że Stownik geograficzny... F. Sulimierskiego znalazł w Galicji dziesięciu prenumeratorów. Oznaczało to, iż tylko jeden na pół miliona mieszkańców tej części kraju był zainteresowany nabywaniem tego wydawnictwa. Korespondent stwierdza: „nieprawdaż, że wielka bieda u nas?”32. Kolejna Korespondencya..., tym razem $z$ listopada 1880 roku, znów jest malo optymistyczna. Sprawozdawca pisze, że „ruch książkowy wzmógł się na chwilę, ale dzieła oryginalne lub pamiątki świeżo wydrukowane, odnoszą się tylko do krótkiego momentu historyi i nie sięgają dalej, jak pół wieku w tyl”33. Mówiąc „pamiątki” korespondent ma na myśli pamiętniki i naukowe opracowania historyczne. Doniesienia „z pola literatury" obfitują w informacje, iz brakuje dziel historycznych w opracowaniu polskich autorów.

Następne lata nie przynoszą większych zmian. W korespondencji ze Lwowa, z grudnia 1883 roku, znajduje się stwierdzenie: „Jeżeli, pomimo gwarności, Lwów od dawna już nie był wesolem miastem, to dziś należy do najsmutniejszych w świecie ${ }^{34}$. Stało się tak przede wszystkim $z$ powodu złych zbiorów i związanego $z$ tym wzrostu cen („drożyzna” - napisal korespondent). Sytuacja gospodarcza miała w tym momencie tak silny wpływ na zachowania mieszkańców Lwowa, że zainteresowanie uczestnictwem $\mathrm{w}$ życiu kulturalnym i umysłowym miasta spadło prawie do zera. Mimo szeroko zapowiadanych przez prasę miejscową literackich odczytów poety Karola Brzozowskiego i powieściopisarza Zacharyasiewicza, spotkania te nie wzbudzily zainteresowania. „Trochę pań, kilka nauczycielek i nieco panien, oto cała publiczność 160 tysiącznego Lwowa”. Brak odzewu ze strony publiczności, zwlaszcza mlodzieży akademickiej, autor tekstu gorzko podsumowal: „odczyt, to nie polędwica $z$ akompaniamentem Pilznera, toteż bardzo mała liczba mężczyzn ukazała się na odczytach..." ${ }^{35}$.

\footnotetext{
${ }^{29}$ Korespondencya ..., „Klosy”, 10:1870, nr 246, s. 168.

${ }^{30}$ Tamże.

${ }^{31}$ Tamże.

${ }^{32}$ Korespondencya czasopisma Ktosy, „Kłosy”, 30:1880, nr 770, s. 215.

${ }^{33}$ Korespondencya ze Lwowa, „Kłosy”, 31:1880, nr 809, s. 427.

${ }^{34}$ Korespondencya czasopisma Ktosy, „Kłosy”, 38:1884, nr 968, s. 44.

${ }^{35}$ Tamże.
} 
W październiku 1889 roku anonimowy korespondent ze Lwowa pisze: „na innych polach niemniej widać gorliwą krzątaninę. Wzrost kółek rolniczych, czytelni ludowych, biblioteczek wiejskich, wypożyczalni jest szybki...”. Ogólnie widać zmiany prowadzące do wydźwignięcia „z galicyjskiej nędzy”36. „Tylko ruch księgarsko-wydawniczy omdlewa. Smutny stan finansowy kraju odbija się przede wszystkiem na wydawnictwach, dlatego liczba ich maleje. Księgarz-wydawca nie może liczyć na zbyt książek, nie chcąc więc narazić się na straty, wydaje jak najmniej"’. $Z$ rozważań autora wynika, że najlepiej mają się dzieła naukowe, gdyż ich wydawanie wspierane jest przez towarzystwa naukowe. W gorszej sytuacji znajduje się literatura piękna, zwłaszcza powieść. „Powieść tuli się w odcinkach czasopism"38, gdyż czytelnicy zadowalają się taką formą i nie są zainteresowani zakupem całych tomów. Podobny obraz publikowania powieści wyłania się kilka numerów wcześniej. W odpowiedzi redakcji na zapytanie czytelnika, pojawia się stwierdzenie: „wobec niezmiernego mnóztwa drukujących się w czasopismach warszawskich powieści, tłumaczonych $z$ różnych języków, niepodobna wiedzieć, ani pamiętać, czy ta lub owa była gdzie umieszczona"39. Tekst ten dotyczy piśmiennictwa warszawskiego, ale uwagę tę można odnieść do całego kraju.

\section{Towarzystwo Oświaty Ludowej we Lwowie}

Przykładem pracy, której celem było przełamanie zniechęcenia i braku zainteresowania ksiażką jest działalność Towarzystwa Oświaty Ludowej we Lwowie. Towarzystwo to, założone w 1881 roku przez historyka dra Aleksandra Hirschberga, liczyło 843 członków, głównie rzemieślników. Mimo dość prężnej organizacji miało ogromne kłopoty $\mathrm{z}$ uzyskaniem odpowiednich funduszy na realizacje zadań ${ }^{40}$. Jego głównym celem było, jak wskazuje nazwa, szerzenie oświaty. Aby móc realizować statutowe zadania, utrzymywało ono cztery czytelnie (we Lwowie, Sądowej Wiszni i Rudkach), dwie bezplatne wypożyczalnie we Lwowie oraz 54 biblioteki wiejskie. Łączną wielkość księgozbioru, należącego do Towarzystwa Oświaty Ludowej, oszacowano na 4493 dzieła w 4878 tomach oraz 90 egzemplarzy czasopism. Korespondent „Kłosów” wyraża uznanie dla działalności dra Hirschberga i jego Towarzystwa. Zastanawia się, jak z tak ograniczonych funduszy stworzono tyle bibliotek i czytelń, wyposażając je bogato. Zwraca uwage na calkowity brak zainteresowania tą sprawą miejscowej prasy. Dramatyczne są publikowane $\mathrm{w}$ tym miejscu dane liczbowe: $\mathrm{w}$ mieście liczącym 100000 mieszkańców aż 30000 ludzi nie potrafiło czytać. W świetle takich danych zasługi dra Hirschberga wydają się być ogromne.

${ }^{36}$ Korespondencya czasopisma Ktosy, „Kłosy”, 49:1889, nr 1271, s. 299.

${ }^{37}$ Tamze.

${ }^{38}$ Tamże.

${ }^{39}$ Korespondencya czasopisma Ktosy, „Klosy”, 49:1889, nr 1266, s. 223.

${ }^{40}$ Środki na dzialalność Towarzystwo pozyskiwało z Landerbanku, lwowskiej Rady Miejskiej, Banku Hipotecznego, Galicyjskiej Kasy Oszczędności oraz z dzialalności teatralnej i odczytów. Zob.: Kłosy", 38:1884, nr 977, s. 181. 


\section{Tanie wydawnictwa Trzecieskiego w Krakowie}

Sposobem na ożywienie ruchu umyslowego i na ułatwienie dostępu do słowa drukowanego biednemu społeczeństwu Galicji miały być tanie wydania. Tanią literaturę piękną wydawal, wspomniany wcześniej, K. J. Turowski. Pierwsza wzmianka na temat wydawania tanich dzieł naukowych pojawiła się $\mathrm{w}$ pierwszym numerze „Kłosów”. Brak było w niej nazwiska pomysłodawcy, ale redakcja zapewniła, że będzie informować czytełników o rozwoju sytuacji. W 1865 roku „Kłosy” w Kronice lwowskiej literackiej $i$ naukowej podały, że pan Trzecieski z Krakowa ma zamiar utworzyć towarzystwo, którego celem byłoby wydawanie „ksiązek polskich, tanich i dobrych"4l. Kilka numerów później, w Korespondencji z 30 grudnia 1865 ze Lwowa, w ramach wiadomości "nie lwowskich” podano, że w Krakowie „ruch literacki zaczyna się ożywiać" "2. Ożywienie to polegało między innymi na tym, że Franciszek Trzecieski zrealizował swój pomysł utworzenia „wydawnictwa dzieł tanich i pożytecznych"43. Jego celem było dostarczanie książek o wysokiej wartości i niewielkiej cenie, aby podnieść poziom oświaty w Galicji. Ich tematyka miała mieścić się w obrębie pięciu działów: moralno-filozoficznego, historii polskiej i powszechnej, umiejętności politycznych i społecznych, nauk ścisłych i przyrodniczych oraz literackiego. Prospekt wydawnictwa zapowiadal, że rocznie ma wychodzić 200 arkuszy, każdy w cenie pięciu centów ${ }^{44}$.

W 1866 roku nakładem „wydawnictwa dzieł tanich i pożytecznych" ukazał się Kalendarz rolniczo-przemystowy, Żywot Kościuszki oraz pierwszy tom Dziejów Polski XVIII wieku ${ }^{45}$. Jakiś czas później w Kronice powszechnej zamieszczono informacje, iz wydawnictwo F. Trzecieskiego opublikowało kolejny tom pracy historycznej H. Szmitta ${ }^{46}$ a obecnie przygotowuje tom drugi Szkoty J. Simona ${ }^{47}$. Trzy tygodnie później pojawiła się nowa wiadomość, że Trzecieski drukuje dzieła Jana Stuarta Milla ${ }^{48}$.

„Kłosy” bardzo pozytywnie odnosily się do działalności wydawniczej Trzecieskiego. Autor Kroniki powszechnej pisal: „chwalebne to ze wszech miar wydawnictwo [...] obiecuje wydać wiele dzieł pożytecznych"49. Odnotował również, że liczba prenumeratorów, ograniczająca się początkowo tylko do terenów Galicji, powoli wzrasta. Faktycznie pierwsza seria zorganizowanego Wydawnictwa Dzieł Tanich i Pożytecznych zakończyła się sukcesem. Dostarczyła swym subskrybentom obiecane wartościowe tomy za niewielką cenę. Kolejna wzmianka

\footnotetext{
${ }^{41}$ Kronika lwowska literacka $i$ naukowa, „Klosy”, 1:1865, nr 19, s. 226.

${ }^{42}$ Korespondencya czasopisma Kłosy, „Kłosy”, 27:1865, nr 27, s. 319.

${ }^{43}$ Tamze.

44 Tamże.

${ }^{45}$ Kronika lwowska literacka i naukowa, "Klosy", 2:1866, nr 36, s. 431.

${ }^{46}$ H. Schmitt, Daieje Polski XVIII i XIX wieku osnowane przeważnie na niewydanych dotąd żródlach, t. 1-2, Kraków 1866.

${ }^{47}$ Kronika powszechna, „Kłosy”, 2:1870, nr 45, s. 520.

${ }^{48}$ Kronika powszechna, "Kłosy”, 2:1870, nr 48, s. 544.

${ }^{49}$ Kronika powszechna, „Klosy", 2:1870, nr 45, s. 520 .
} 
o działalności F. Trzecieskiego ${ }^{50}$ pojawiła się w „Kłosach” w roku 1870. Otóż, jak podano, jego staraniem zawiazało się Towarzystwo Przyjaciół Oświaty, które za roczną składkę 10 guldenów zobowiązało się dostarczać swoim członkom dzieła „najcelniejszych pisarzy”: L. Siemieńskiego, W. Pola i J. Szujskiego ${ }^{51}$. Jednakże bilans niespełna dwuletniego istnienia Towarzystwa Przyjaciól Oświaty wypadł bardzo słabo. „Kłosy” podały, że w 1870 roku liczyło ono trzystu czlonków, $z$ których na walne zebranie zebrało się ledwie siedmiu. Mimo dobrego pomysłu zabrakło konsekwencji w jego realizacji. Czlonkowie Towarzystwa opieszale realizowali zadania statutowe. Przedsięwzięcie upadło, ponieważ samym zainteresowanym zabrakło energii do działania. Redaktor gorzko podsumowal, ze nie sposób zdziałać cokolwiek w dziedzinie edukacji, „jeżeli przyjaciele oświaty są nieprzyjaciółmi tejże"

\section{Literatura ludowa}

Największą potrzebą w Galicji była oświata ubogich warstw społecznych. "Kształcenie ludu, podjęte w Galicyi przed laty kilkudziesięciu, wlokło się leniwo" - pisze E. Zorjan w artykule poświęconym oświacie w Galicji ${ }^{53}$. Dopiero lata osiemdziesiąte przyniosły postęp polegający między innymi na szerzeniu oświaty poprzez wydawnictwa ludowe. Określenia „oświaty ludowej” czy „literatury ludowej” nie były jednoznaczne. O ile „ludowa” znaczyło zawsze „przeznaczona dla ludu”, o tyle „oświata” czy „literatura” rozumiane były przez autorów artykulów bardzo różnie. W zależności od prezentowanych poglądów społecznych widziano oświatę jako jedynie naukę czytania, lub rzadziej - jako rozwój na poziomie świadomości społecznej i narodowej. „Literatura ludowa” była równiė pojęciem szerokim. Mieściły się w nim zarówno powiastki rozrywkowe, jak i mające charakter moralizatorski, ewentualnie przybliżające wiedze historyczną. Obok nich znajdowały się poradniki dotyczące pracy na roli i broszurki instruktażowe o prawach obywatelskich.

\footnotetext{
${ }^{50}$ Wydawnictwo Dzieł Tanich i Pożytecznych nie było pierwszym pomysłem F. Trzecieskiego. Już w roku 1848 we Lwowie załozył on wydawnictwo pod nazwą Biblioteka Połska w Tanich Wydaniach. Niestety pierwszy naklad tego wydawnictwa zostal skonfiskowany. Zamierzenie wydawania Biblioteki Narodowej w Tanich Wydaniach zostało przerwane przez wybuch powstania styczniowego. Dopiero w 1865 udało się F. Trzecieskiemu zrealizować zamierzenia. Wydawnictwo Dziel Tanich i Pożytecznych opierało się na subskrypcji. $Z$ założenia mialo wydawać prace popularnonaukowe $z$ różnych dziedzin wiedzy. Do współpracy udało się Trzecieskiemu pozyskać J. Szujskiego, A. Młockiego, J. I. Kraszewskiego. Pierwsza seria zakończyla się sukcesem. Druga napotykała już na problemy finansowe. $Z 1400$ czlonkow-subskrybentów pozostalo tylko 800 . W 1870 roku Trzecieski przekształcil Wydawnictwo w Towarzystwo Przyjaciół Oświaty w Krakowie. Niestety zarząd Towarzystwa (A. Potocki jako prezes) działał opieszale a sam inicjator zrezygnował $z$ wiceprezesury. W 1871 roku Towarzystwo upadlo. W 1872 roku księgarnię wraz z wypożyczalnią kupil A. Dygasiński. Zob. J. Stąsiek, Trzecieski Franciszek, w: Stownik pracowników ksiazzki polskiej (dalej cyt. SPKP), pod red. Ireny Treichel, Warszawa-łódź 1972, s. 912.

${ }^{51}$ Korespondencja czasopisma „Ktosy”, „Klosy”, 10:1870, nr 246, s. 168.

52 Tamże.

${ }^{53}$ E. Zorjan, Kartka z dziejów oświaty ludowej w Galicyi, „Kłosy”, 38:1884, nr 983, s. 282.
} 
Mimo, iż praca oświatowa w latach osiemdziesiątych nabrala tempa, potrzeby ciągle byly ogromne. Bariere w rozpowszechnianiu literatury ludowej stanowili sami odbiorcy. Galicja, jako kraj ubogi, przeznaczała na oświatę niewielkie pieniądze. W 1884 roku dwa tysiące wsi nie miało szkólek ludowych. E. Zorjan pisze o funkcjonującym systemie stypendialnym, „którem się Galicja prawdziwie chlubić może"54. Niestety nie obejmowal on szkolnictwa podstawowego. Doskonale redagowane, według autora artykułu, pisma ludowe „Dzwonek”, „Włościanin” i wiele innych „po krótszej lub dłuższej walce upadły”. Wa. Walka ta polegala na zdobywaniu czytelników. Autor artykułu określił to w następujący sposób: „Byt pism nazwaliśmy walką, tak było istotnie; upadły one wprawdzie, lecz zdobyły wiele: wywalczyły prawo istnienia swoim następcom” "K6. „Kłosy" podają, ze w 1884 roku istniały następujące pisma ludowe: katolicka „Chata”, wydawana przez Macierz Polską „Niedziela” oraz redagowane przez ks. S. Stojałowskiego: „Wieniec” i „Pszczółka”57.

Pisząc o ludziach zaangażowanych w pracę oświatową, autor tekstu stwierdza: „żadne nazwiska nie występują na jaw, ale cale grono”. Byli to młodzi ludzie, z wykształceniem uniwersyteckim, zwykle bez zasobów finansowych, ale pełni wiary $w$ idee. Pracowali uczciwie i bez rozgłosu. Pierwszy formalny komitet, wydający książki dla ludu, zawiązał się pod przywództwem Alfreda Młockiego ${ }^{58}$. Później „kilku posłów sejmu galicyjskiego utworzyło komitet, sejm uchwalił stałą zapomogę i odtąd co miesiąc wychodzi z pod prasy drukarskiej jedna książeczka w języku polskim, druga w rusińskim"59. Działalność tego komitetu podsumowano liczbą 80 tysięcy egzemplarzy. Redaktorem pierwszej serii był Kazimierz Okaz, ,jeden $z$ najpierwszych i najgorliwszych krzewicieli oświaty ludowej"60, którego „Kłosy” chwalą za staranny dobór treści i formy oraz przemyślany kolportaz.

${ }^{54}$ E. Zorjan, Kartka z dziejów oświaty ludowej w Galicyi, „Klosy”, 38:1884, nr 983, s. 282.

55 „Kłosy”, 38:1884, nr 983, s. 283.

56 "Tamże.

57 „Wieniec” i „Pszczółka” były dwutygodnikami ukazującymi się zamiennie (w celu ominięcia prawa austriackiego). W 1875 nabył je od Czesława Pieniażka ks. Stanisław Stojałowski. Ukazywały się początkowo we Lwowie, później w Czacy na Węgrzech. w Cieszynie i Bielsku-Białej. Były to pisma organizujące kulturę wsi galicyjskiej. Od 1900 roku wychodziły pod wspólnym tytułem „WieniecPszczółka”. Ks. Stojałowski za działalność społeczno-polityczną był często więziony. Przez whadze kościelne został ekskomunikowany (zob. A. Wadowski, Stojatowski Stanistaw, w: SPKP, s. 857-859). Prasa katolicka pisma ludowe piętnowała jako „zgubne dla wiary świętej”. Tak oceniano też te, prowadzone przez ks. Stojalowskiego. Jego działalność budziła niezwykłe wrogie nastawienie kleru i ludzi zamożnych. Ogloszono nawet list pasterski trzech biskupów, w którym zakazywano chlopom czytania pism ludowych „Wieńca” i „Pszczółki”. Zob. J. Potoczny, Od alfabetyzacji do popularyzacji wiedzy, Rzeszów 1993, s. 93.

58 „Przegląd Lwowski” pod redakcją ks. E. Podolskiego krytycznie wypowiadal się o osobie A. Mlockiego jako glównego odpowiedzialnego za zawiązane we Lwowie Towarzystwo Wydawnictw Ludowych. Zarzucal mu brak przywiązania do Kościola. Podobne emocje budziła postać pochwalanego przez „Kłosy” autora ludowych ksiązeczek P. Zbrożka. Zob.: J. Potoczny, Od alfabetyzacji..., s. 87.

${ }^{59}$ „Klosy”, 38:1884, nr 983, s. 283.

${ }^{60}$ Tamże. 


\section{Komitet Wydawnictwa Dzielek Ludowych}

Dzialający we Lwowie, Sejm Krajowy wspomógł „komitet wydawnictwa dziełek ludowych", który aż do początku XX wieku, zajmował się wydawaniem „książeczek dla ludu”61. Ten oficjalnie działający Komitet swoje korzenie mial w popartej przez Sejm inicjatywie A. Młockiego. Głównym celem i zadaniem komitetu było „oświecenie ludu”. „Zrozumiano trzy główne potrzeby ludu i w tym kierunku pracowano" ${ }^{2}$. Za najważniejsze współcześni uważali: utrwalanie wiary, poznanie historii oraz wzbudzenie świadomości spolecznej. Te trzy drogi oświaty ludowej prześledzil E. Zorjan w swoim tekście prezentując tytuły wydawane przez Komitet.

„Chłop, zapytany o narodowość, odpowiada: jestem chrześcijanin” - $z$ tego powodu postulowano kształcenie chlopa poprzez treści religijne. Wydawanie i rozpowszechnianie ksiażek takich jak Żywot św. Wojciecha czy $O$ kościele $i$ cudownym obrazie N. Maryi Panny w Częstochowie to sposób na „nauczenie wieśniaka dziejów jego wiary”, gdyż jak stwierdzil autor artykułu: „religijność zaciekawia, pociąga do ksiażki, a książka uczy"63. Wiedzę historyczną upowszechniano przy pomocy opowieści o udziale chłopów w wydarzeniach historycznych. „W tym kierunku zrobil Komitet lwowski krok pierwszy, wielkiej doniosłości; utorował drogę nauce historyi ziemi rodzinnej. Rzucono kilka opowiadań historycznych, które od razu trafily do serc ludu. Bo jakżeby chłop nie miał czytać o Bartoszy z Trembowli!"'i4. Podobne książki pisal Walery Łoziński, który publikował pod pseudonimem Walenty ze Smolnicy. Seria nosiła tytul „Ludzie z pod slomianej strzechy”. Sam autor tak zapowiadał swoje prace: „Będzie tam opowiadanie o wielu ludziach, $z$ bardzo dawnych i niedawnych czasów, co pod słomianą urodzili się strzechą, a bądź cnotą, bądź nauką, bądź milością ojczyzny, bądź poświęceniem za swój naród wsławili się między swoimi i wznieśli nad stan wieśniaczy"65. Bohaterami tych powiastek byli: Król-Kołodziej, Tomko Brodzic (który uratował życie królowi Kazimierzowi), Paweł Cholewa (który wskazał wroga Bolesławowi Śmiałemu), Maćko (który jednym cięciem ściął trzy głowy krzyżackie i z tego powodu nosil później miano Zerwikaptur). Czyny tych bohaterów miały przekonać czytelników wywodzących się z chłopstwa, że ich i wyższe warstwy społeczne łączy wspólna narodowa historia.

Sytuacja spoleczno-polityczna, w jakiej znalazła się Galicja po uzyskaniu autonomii, pokazala, że społeczeństwo było nieprzygotowane do korzystania ze swoich praw. Otóż „lud, pozbawiony światła, został nagle powołanym do akcyi, o której nie miał wyobrażenia. Autonomia, nadana Galicyi, znalazła po wsiach grunt zupełnie jałowy. Włościanin miał się sam rządzić, ustanowiono dlań prawa

${ }^{61}$ E. Zorjan, Kartka z dziejów..., „Klosy”, 38:1884, nr 984, s. 300.

${ }^{62}$ Tamze.

${ }^{63}$ Tamże.

${ }^{64}$ Jest to opowiesć (.,przez Piotra Zbrożnego, jednego z najzdolniejszych naszych pisarzy ludowych") o udziale Bartosza w wojnie $z$ Krzyżakami, $z$ której wraca zwycięsko otrzymując jako nagrodę uznanie króla i narodu. Zob. E. Zorjan, Kartka z dziejów..., „Kłosy", 38:1884, nr 984, s. 300.

${ }^{65}$ Tamże. 
i część onych oddano jego własnej pieczy. Gmina miała teraz własne urzędy wybieralne, ale tysiączny ledwo mial o nich pojęcie" ${ }^{m 6}$. W takich warunkach zrodziła się potrzeba wydawania książek o charakterze informacyjno-instruktażowym. Komitet wydawal książeczki, które dostarczaly konkretnych rad, jak w nowej rzeczywistości mają postępować włościanie, jakie przysługują im prawa i w jaki sposób mają z nich korzystać. Przykładowe tytuły to: Rada gminna, Jak się wybiera radę gminna i naczelnika gminy (P. Zbrożek) ${ }^{67}$.

Kolejnym problemem, doktóregorozwiązania miała przyczynićsię działalność wydawnicza omawianego Komitetu, była galicyjska nędza. „Lud usamowolniony, ale ciemny, bezradny [...] Bieda podkopuje podwaliny dobrobytu, a o lekarstwo na nią bardzo trudno" - pisze Zorjan. Łatwo bylo chłopom popadać w ogromne zadłużenie $\mathrm{z}$ powodu zaciągania lichwiarskich kredytów. Ustawę normującą wysokość oprocentowania pożyczek uchwalono dopiero w 1877 roku. W odpowiedzi na ten problem Komitet wydal Opowiadanie o lichwie $i$ towarzystwie zaliczkowym $^{68}$. Ciekawą inicjatywą było ogłoszenie przez Komitet konkursu na dzieło, które poruszając „wszystkie sprawy naszego ludu” połączyłoby rozrywkę $z$ nauką. „Suchy wykład odstręczyłby pewno czytelników, nie nawykłych jeszcze do książki; trzeba ją więc było napisać zajmująco, ażeby chłop czytając, bawił się [...], a jednak odniósł korzyść, nauczył się czegoś” ${ }^{9}$. Konkurs wygrał nieznany nikomu Józef Hopcas, autor opowiadania Stary Grzegorz. Jego drugi utwór Jak to często bywa na wsi poruszał problematykę pijaństwa. „Świadomość celu i znajomość stosunków ludowych w Galicyi pozwala Komitetowi coraz bardziej rozwijać swą działalność..."70. Praca Komitetu zdobyła uznanie. Jego wydawnictwa oceniano jako wartościowe i odpowiadające potrzebom czytelników, dla których były przeznaczone.

Podsumowując działania Komitetu w dziedzinie literatury ludowej E. Zorjan pisze: „Powieści, opowiadania historyczne, zręczne rozwijanie kwestyi społecznych - wszystko to składa się na piękną wiązankę, która na kartach naszej literatury ludowej złotymi zgłoskami będzie wypisaną" ${ }^{71}$.

Działania w sferze literatury ludowej uzupełniają obraz ruchu wydawniczego w Galicji. Mimo wielu trudności praca trwa a sam Komitet, jak zauważa autor artykułu, nie pozostaje osamotniony. „Ruch na polu wydawnictw wzmaga się, a tuż obok dzialalności Komitetu należy wspomnieć o Macierzy, której może kiedyś poświęcimy oddzielną wzmiankę. Ona dopiero rozpoczęła pracę na niwie, przygotowanej przez innych. Tamtym więc oddaliśmy pierwszeństwo."72 Tak więc praca Komitetu przygotowała grunt dla innych organizacji, działających na rzecz oświecenia niższych warstw społecznych.

\footnotetext{
${ }^{66}$ Tamże, s. 301.

67 Tamże.

${ }^{68}$ Tamże.

69 Tamże.

${ }^{70}$ Tamże.

${ }^{71}$ Tamże.

${ }^{72}$ Tamże.
} 


\section{Macierz Polska}

W Korespondencji czasopisma Kłosy ze Lwowa w 1880 roku znalazła się informacja o działalności Towarzystwa Literackiego ${ }^{73}$. Zbierało się ono $\mathrm{w}$ tym czasie co dwa tygodnie „jako poufne”. Przystapilo doń 60 członków, „pracowników na polu nauki i piśmiennictwa" (wśród czlonków Towarzystwa znalazl się prof. A. Małecki) ${ }^{74}$. Na jednym ze spotkań odczytano list J. I. Kraszewskiego, w którym pisarz prosil Towarzystwo Literackie o opracowanie statutu dla Macierzy Polskiej ${ }^{75}$.

W grudniu 1883 roku w „Klosach” zamieszczono dane dotyczące wydawanych i rozpowszechnianych przez Macierz Polską książek. W 1882 roku liczba „puszczonych w obieg” książeczek wyniosła około 40000 . Był to doskonały rezultat, gdyż Rada wykonawcza rozpoczęła działalność w marcu 1882 roku a ksiażki były sprzedawane, nie rozdawane. Adresatem wydawnictw Macierzy była ludność wiejska. Jak trudne to było zadanie, „kto zna naszego wieśniaka, wie dobrze” - pisał korespondent - „ile potrzeba sprężystości i wytrwałości, aby mu ksiązeczkę sprzedać" ${ }^{\prime 6} . Z$ tego wynika, iż Macierz Polska byla prężnie działającą organizacją. Wśród rozpowszechnianych przez nią książek autor korespondencji wymienia powiastkę „Cudowne leki” i zbiór klechd ludowych „Dobry syn”, jako „książeczki użyteczne i dobrze napisane" ${ }^{\text {"7 }}$.

W 1884 roku w „Kłosach” znalazła się lakoniczna informacja o działalności Macierzy: „Wydawnictwa Macierzy rozchodzą się szybko po całym kraju”. Autor podkreśla, że nie jest to tylko i wyłącznie jej zasługą, ale że sukces opiera na pracy jej poprzedników ${ }^{78}$.

\section{Ksiażki szkolne}

Źródłem wiedzy o sytuacji na rynku książki i czasopism w Galicji jest stała rubryka „Kłosów” Kronika lwowska literacka, naukowa i artystyczna. Korespondent podpisujący się inicjałami Em. charakteryzuje zachodzące zmiany, informuje o nowościach, dokonuje podsumowań i ocen. W takim kontekście jawi się informacja dotycząca książek szkolnych. „Niestety, my, nie możemy poszczycić

${ }^{73}$ W roku 1890 „Kłosy” zamieścily w Wiadomościach bieżq̨cych ... informacje, że lwowskie Towarzystwo Literackie im. A. Mickiewicza zapowiedzialo wydanie bibliografii mickiewiczowskiej oraz krytycznego wydania dzieł poety. Prace prowadzono pod kierunkiem prof. R. Pilata. Przygotowywano się także do stworzenia biblioteki mickiewiczowskiej. W tym celu gromadzono autografy wieszcza, cenne i rzadkie wydania oraz publikacje o Mickiewiczu. Zob. Wiadomości bieżące..., „Klosy”, 50:1890, nr 1290, s. 190.

${ }^{74}$ Korespondencja ..., „Klosy”, 30:1880, nr 770, s. 215.

${ }^{75}$ J. I. Kraszewski byl zalożycielem Macierzy Polskiej we Lwowie. Powstala ona w 1882 roku. Działała na zasadzie fundacji. Kraszewski pozostał jej dożywotnim kuratorem. W pierwszym okresie działalności Macierzy przewodniczył A. Małecki. W latach 1894-1891 stanowisko to objął W. Łoziński. Pod jego zarządem Macierz zainicjowała wydawanie „Biblioteki Macierzy Polskiej”. Zob. J. Potoczny, Od alfabetyzacji..., s. 89.

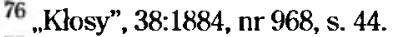

77 Tamże.

${ }^{78}$ „Kłosy”, 38:1884, nr 983, s. 283. 
się zbyt wielką liczbą dobrych, nowych książek szkolnych: prawda, że po części i stosunki, w których zostajemy są temu winą"79 - pisze Em. Bardzo ceni wartość wykształcenia i w tym duchu wymienia najnowsze dokonania w tej dziedzinie.

Wśród wymienionych przez niego tytułów znalazły się: kolejny (piąty) zeszyt Poczqtkowych zasad chemii Z. D. Hałatkiewicza (Bochnia, W. Pisz, 1865), zeszyt jedenasty Stownika polsko-tacińskiego ks. A. Bielikowicza i zeszyt pierwszy tomu drugiego Dziejów powszechnych z dziejobrazem powszechnym S. Zarańskiego ${ }^{80}$. Pozostałe tytuły to tylko zapowiedzi wydawnicze. Wśród nich znajduje się informacja, że prof. B. Trzaskowski ${ }^{81}$, profesor gimnazjum w Rzeszowie, przełożył podręczniki do nauki greckiego (gramatykę i ćwiczenia), lecz trudno jest mu znaleźć nakładcę, „bo rzecz kosztowna" ${ }^{2}$. W Krakowie nakładem Himmelblaua ma wyjść Historya powszechna thumaczona $z$ niemieckiego przez H. Sawczyńskiego i Wypisy francuskie przełożone przez Świtkowskiego. W 1866 roku zanotowano przygotowaną do druku pracę J. N. Gnatowskiego Rys dziejöw Księstwa Oświęcimskiego i Zatorskiego. Gnatowski przedłożył tę ksiażkę komisji edukacyjnej działającej przy sejmie galicyjskim ${ }^{83}$. Do szkół w Galicji wprowadzano również podręczniki wydane poza jej granicami. Przykładem może być odnotowana przez „Klosy” w 1866 roku Zoologia z atlasem, która ukazała się nakładem Lesmana w Warszawie ${ }^{84}$.

W 1880 roku korespondent „Kłosów” ze Lwowa pisał o nowych ksiażkach, wymieniając wśród nich pełne humoru Wspomnienia obywatelskie A. Wilczyńskiego. Przedstawil również, ale tylko „dla kronikarskiej sumienności”"5, Zapiski pedagoga E. Gergowicza, nauczyciela szkoły miejskiej. W tym samym miejscu „Kłosy” podały ciekawą informację dotyczącą działań Towarzystwa Pedagogicznego. Towarzystwo to zaczęło w tym czasie wydawać tanie dzieła naukowe w ramach serii - „Biblioteka dla nauczycieli szkół ludowych”. W 1880 roku ukazal sie jej dziewiąty tom, zawierający drugie wydanie Listów pedagogicznych A. Józefczyka. Nakladem Towarzystwa Pedagogicznego ukazało się również „bardzo użyteczne dla wszystkich pań, dzielko panny Anieli Grzywińskiej: Nauka robót ręcznych kobiecych. Napisana według programmatu dla szkół żeńskich"\$6. Książka ta omawia praktyczną naukę robót szydełkowych oraz kroju i szycia. Zaliczono ją do książek szkolnych, ponieważ odpowiadala wymogom nauczania w szkołach przeznaczonych dla dziewcząt.

${ }^{79}$ Em., Kronika lwowska literacka, naukowa i antystyczna, „Kłosy”, 1:1865, nr 9, s. 108.

${ }^{80} \mathrm{O}$ ukazaniu się tomów 1 i 2 Dziejów powszechnych „Kłosy” informowały kilka numerów wcześniej. Tom 1 ukazał sie w 1857 roku w Wiedniu, tom 2 od 1865 roku w Krakowie w formie zeszytów. Patronat objęlo Towarzystwo Naukowe Krakowskie, uznając tę pracę za podręcznik dla szkół. Zaplanowano jeszcze cztery tomy. Miały one obejmować dzieje powszechne $z$ uwzględnieniem dziejów narodów slowiańskich w tym Polski. Praca ta jednocześnie ukazywała się po niemiecku w Wiedniu.

${ }^{81}$ Bronislaw Trzaskowski był również autorem dzieła Sloworód polski oraz podręczników do nauki języka polskiego, również gramatyki. Zob.: „Kłosy”, 1:1865, nr 1, s. 11.

82 „Klosy”, 1:1865, nr 9, s. 108.

${ }^{83}$ Kronika powszechna, „Klosy”, 2:1866, nr 40, s. 479.

${ }^{84}$ Kronika powszechna, „Kłosy”, 3:1866, nr 63, s. 152.

${ }^{85}$ Korespondencja czasopisma Ktosy, „Klosy”, 30:1880, nr 770, s. 215.

${ }^{86}$ Tamże. 
Wśród Nowości kolendowych także pojawiają się książki o charakterze oświatowym. Przykładem może być Królestwo zwierząt w przekładzie A. Dygasińskiego $^{87}$. Była to ksiazżka adresowana do młodzieży. Ksiaż̇ka uznawana za szkolną nie musiała być zatwierdzona przez wladze jako podręcznik. Kryterium pozwalającym na zaliczenie jej do tej grupy był adresat (młodzież szkolna) i zamysł autora (zamiar wykorzystywania w procesie nauczania na poziomie podstawowym lub gimnazjalnym). Powszechne w tym okresie było pisanie podręczników przez profesorów gimnazjalnych (np. B. Trzaskowski) oraz wyższych uczelni. Książką szkolną w Galicji interesowano się szczególnie, zwłaszcza, że trafiała ona także do Polaków w zaborze rosyjskim i pruskim, gdzie działania wynaradawiające przybierały najostrzejszą formę. I chociaż oceny poziomu tych ksiażek dokonywane przez redaktorów „Kłosów” często są surowe, niewątpliwie wskazują na ich przydatność.

\section{Wydawnictwa naukowe i fachowe}

Prace naukowe, fachowe i ekonomiczne ukazujące się w Galicji znajdują najwięcej pochwał w rubrykach „Kłosów”, jako niezbędne dla rozwoju kraju.

W 1865 roku korespondent „Kłosów” pisze o ukazującej się właśnie we Lwowie Szkole polskiej gospodarstwa spotecznego J. Supińskiego. Owszem, autor korespondencji pochwala ideę przybliżenia badań zagranicznych Polakom, ale to, jego zdaniem, nie wystarczy. Pisze on, że w sprawie własności ziemskiej „autor (Supiński - przyp. D.F.) nie umie postawić definicji lepszej i kołuje nie wiele zaprzeczając i nie wiele dowodząc", czyli nie zajmuje jednoznacznego stanowiska ${ }^{\text {g8 }}$. Aprobatę recenzenta zdobywa pogląd, że rozwój przemysłu uzależniony jest od poprawy sytuacji na wsi, wobec czego niezbędne staje się wprowadzenie reformy rolnej. Praca ta polecana jest jako „pouczające dzieło" dla ziemiaństwa w intencji zmiany stosunków społecznych ${ }^{89}$.

W Korespondencji... z 30 lipca 1866 roku $z$ Krakowa znalazły się informacje o tym, iż ukazała się tam Historya Polski za panowania Jana Kazimierza. Napisał ją profesor uniwersytecki Antoni Walewski. Sama praca, jako historyczna, zasługuje na uwagę a jej temat wzbudza zainteresowanie badaczy, ale poglądy autora zyskują miano „średniowiecznych" ${ }^{\text {90 }}$. W 1870 roku w Wiadomościach bieżacych... podano informację o tym, iż w Krakowie S. Krzyżanowski wydal niewielki objętościowo Stownik heraldyczny dla pomocy w poszukiwaniach archeologicznych (liczył on łącznie około 80 stron). Był to alfabetyczny spis herbów występujących na zabytkach, oprawach dzieł i rękopisów.

W styczniu 1880 roku w liście J.I. Kraszewskiego do „Kłosów” znalazła się informacja o tym, że firma Gubrynowicza i Schmidta wydała we Lwowie

\footnotetext{
${ }^{87}$ Nowości kolendowe, „Kłosy”, 48:1889, nr 1229, s. 39.

${ }^{88}$ Korespondencja czasopisma „Ktosy”, „Klosy”, 1:1865, nr 11, s. 127.

${ }^{89}$ Tamże.

${ }^{90}$ Korespondencja czasopisma „Ktosy”, „Kłosy”, 3:1866, nr 58, s. 69
} 
wznowienie "całkowicie przerobione i znacznie powiększone" ${ }^{91}$ Systematu Ekonomii Spotecznej autorstwa Leona Bilińskiego (byłego rektora Uniwersytetu Lwowskiego). Praca ta była wynikiem kilkuletnich badań autora nad stanem współczesnej nauki, w świetle literatury zachodniej Europy oraz calości literatury polskiej, zwłaszcza prac J. Supińskiego. Mówiąc o pracach Supińskiego, J. I. Kraszewski stwierdza, że: „owoc takiej pracy, mające wielką doniosłość dla nauki gospodarstwa społecznego" jest „u nas dosyć dyletancko traktowane”92. Pisarz zachęca do lektury Systematu... i podjęcia dyskusji.

Na początku roku 1884 „Kłosy” odnotowały kilka tytułów prac $z$ grupy wydawnictw naukowych $\mathrm{i}$ fachowych. Wśród nich znalazły się: podręcznik do matematyki dla młodzieży szkół wyższych (Zasady algebry wyższej W. Zajączkowskiego, profesora Politechniki Lwowskiej), do geologii J. Niedźwieckiego (o kopalniach soli w Wieliczce i Bochni) oraz Ochrona wtasności rolnej i Kucie koni. Wszystkie wymienione prace zostały wydane przez lwowską firmę Gubrynowicz i Schmidt. W tym samym czasie, w Krakowie, ukazała się praca $W$ sprawie przemystu krajowego autorstwa T. Rutkowskiego ${ }^{93}$.

Przedstawione powyżej prace dotyczą glównie ekonomii i socjologii. Ich celem było poszukiwanie drogi wyjścia z galicyjskiej biedy i uporządkowanie spraw społecznych. Józef Supiński, czołowy socjolog tych czasów, w swoich pracach wskazywał potrzebę podjęcia reform gospodarczych na ziemiach polskich, które do tej pory nie były dobrze widziane przez konserwatywny obóz szlachecki w Galicji, mimo doświadczeń 1846 roku $^{94}$.

\section{Problem rozdrobnienia wśród czasopism}

Obok produkcji książkowej w Galicji rozwijało się także czasopiśmiennictwo. Czasopisma galicyjskie, podobnie jak książki, napotykały trudności ekonomiczne. Walczyły o prenumeratorów, lecz w związku $z$ ubóstwem społeczeństwa nie miały siły przebicia.

Kronika lwowska czy też Korespondencje ze Lwowa zawierają dużo lakonicznych informacji, dotyczących czasopiśmiennictwa na terenie Galicji. Wymieniane są tytuły nowopowstających pism oraz ogłaszane ich upadki. Towarzyszy temu powtarzający się scenariusz, według którego rodzi się cenna inicjatywa - pomysl na czasopismo, następnie po ukazaniu się prospektu zbiera zbyt mała liczbę prenumeratorów i po krótszym lub dłuższym czasie upada. Przyczyny upadku zwykle bywaja jednakowe - brak czytelników, brak nabywców, brak pieniędzy na kontynuowanie wydawnictwa.

91 Listy J. L. Kraszewskiego, „Klosy”, 30:1880, nr 760, s. 51.

${ }^{92}$ Tamże.

93 „Kłosy”, 38:1884, nr 977, s. 181.

94 Jerzy Potoczny przytacza wypowiedź P. Popiela w sprawie ograniczania dostępu do edukacji ludności wiejskiej („Czas”, 1889, nr 74): „Przymus szkolny to potworność. Nauka nie powinna być bezplatna i obowiazzkowa. [...] Szkoła powinna być wyznaniowa i ograniczona w nauce."; zob. J. Potoczny, Od alfabetyzacji..., s. 12. 
„W Galicyi piśmiennictwo pozostaje w oplakanym stanie" - pisano w roku $1866^{95}$. We Lwowie przestały wychodzić „Tygodnik naukowy i literacki” oraz „Przyjaciel dzieci”. „Dzwonek” i „Gwiazdka cieszyńska” chylą się ku upadkowi. „Nowiny ze Świata” mają pięćdziesięciu prenumeratorów. W Krakowie wyszedł prospekt pisma dla kobiet „Kalina”. Tyle informacji skomasowanych w jednej, niedużej rubryce. Tak te $\dot{z}$ wyglądało życie czasopism galicyjskich - dużo inicjatyw o krótkim istnieniu.

Autor ukrywający się pod kryptonimem S... ${ }^{96}$ problem rozdrobnienia inicjatyw wydawniczych w czasopiśmiennictwie ujął w sposób następujący: „Z noworocznym deszczem [...] spadło na nas co niemiara nowych literackich publikacyi" ${ }^{\text {"y }}$. Nie licząc się z potrzebami i możliwościami czytelników, zapominając o potrzebie znalezienia prenumeratorów „około każdego Nowego Roku pojawiają się programy nowych pism" ${ }^{\text {98 }}$. Ponieważ Galicja nosi miano „prowincyi, nieodznaczającej się zbytniem zamilowaniem do czytania i pracy", nowe pisma nie maja szans na utrzymanie się. Pomysły te rodzą się w glowach "mlodych literatów”, wśród których nie ma takiego „któryby choć raz w życiu nie był zalożycielem, wydawcą i redaktorem przynajmniej jednego czasopisma" ${ }^{\prime 9} . Z$ tego też powodu pisma literackie prezentują poziom mierny, i nie tylko winą czytelników jest ich krótka egzystencja, lecz także ich autorów, ponieważ nie potrafią zaciekawić odbiorców. Rozdrobnienie nie służy ani interesowi wydawcy, ani czytelnikowi, ani poziomowi pisma. Korespondent proponuje skupienie się wokół jednego pisma literackiego w Krakowie i jednego we Lwowie.

Utworzenie w 1865 roku trzeciego czasopisma archeologicznego w Krakowie, o tytule „Nasze Zabytki”, stało się punktem wyjścia do rozważań nad rozdrobnieniem wśród czasopism. Powstanie trzeciego tytułu o tej samej problematyce, nie rokowało dobrze ani już istniejącym, ani temu nowemu. $W$ dobie biedy i małego zainteresowania literatura naukową drobne przedsięwzięcia prasowe nie miały racji bytu. Gdyby współdziałały, „mogłyby utworzyć przedsięwzięcie rokujące dłuższe trwanie"100. W sytuacji bieżącej, trudności ze zdobyciem prenumeratorów powiększane jeszcze przez konkurencję, powodowały krótkotrwałość czasopism.

Także w 1865 roku wspomniany wcześniej K. J. Turowski rozpoczął wydawanie w Przemyślu dwutygodnika „Prawda”101. Kilka tygodni później w „Kłosach” podano, iż wyszedł pierwszy zeszyt „Prawdy”, lecz mimo rozesłania prospektów w ilości 6000, zgłosiło się niewielu abonentów. Jak wynika z lektury „Kłosów” wiele pism zawieszano na pewien czas lub całkowicie likwidowano $\mathrm{z}$ braku na-

95 „Kłosy", 3:1866, nr 62, s. 120.

96 "Mógł to byc Waclaw Szymanowski, uwzględniony w spisie współpracowników w „Kłosach”. Zob.

A. Bar, Stownik..., t. 2, s. 121.

${ }_{97}$ S..., Korespondencya czasopisma Ktosy, „Klosy”, 10:1870, nr 241, s. 84.

98 Tamże.

99 Tamże.

100 "Klosy", 1:1865, nr 3, s. 35.

${ }^{101}$ Kronika lwowska,... „Kłosy”, 1:1865, nr 9, s. 108. 
bywców. Upadające pisma gromadziły po kilkudziesięciu prenumeratorów, co nie dawało im żadnej szansy na przetrwanie. W Krakowie po trzyletnim zawieszeniu ponownie zaczęły wychodzić „Nowiny ze Świata”.

Najważniejszym problemem, $z$ którym musieli zmierzyć się wydawcy w Galicji, była panująca bieda i zacofanie. Stąd tė̇ największy nacisk kładziono na wydawnictwa o profilu ekonomicznym. Czasopisma dawały doskonałe pole do szerzenia światłych pomysłów i idei. Omawiana wcześniej literatura ludowa także poruszała problemy ekonomiczne. $Z$ wielkim entuzjazmem „Kłosy” przyjęły wiadomość o tym, iż w Tarnowie ma ukazywać się nowe pismo ekonomiczne. Już na wstępie pomysłodawcy uzależnili realizację projektu od „poparcia spolecznego"102, czyli od tego czy planowane pismo znajdzie prenumeratorów.

W marcu 1890 roku, korespondent ze Lwowa donosil o głodzie i zapaści ekonomicznej w Galicji. Jest to powtarzający się temat we wszelkich doniesieniach $z$ tych rejonów kraju. $Z$ tego powodu pojawienie się na rynku galicyjskim jednocześnie dwóch tytułów o programie ekonomicznym, wywołało radość. „Ekonomista polski” $i$ „Tygodnik ekonomiczny" miały rozpocząć gospodarczą naprawę kraju. Miesięcznik „Ekonomista” po ukazaniu się dwóch pierwszych numerów zdobył wielkie uznanie w oczach dziennikarzy, którzy oceniali jego poziom jako porównywalny do czasopism zagranicznych. „Tygodnik ekonomiczny” mial być pismem ekonomiczno-przemysłowo-handlowym, które mimo, iż było organem lewicowym, otrzymało pochwałe od konserwatywnego, krakowskiego „Przeglądu Powszechnego”, o czym poinformowano w „Kłosach”. Redakcja „Klosów” także oceniła tygodnik pozytywnie. Jedyną uwaga, na jaką sobie pozwoliła, byla prośba o większą dbałość językową („czystą polszczyznę”) ${ }^{103}$. Z prowincjonalnych miast chlubnie zapisał się Przemyśl, gdzie wychodziły w tym czasie dwa czasopisma ekonomiczne. Jednym $z$ nich byl „Przewodnik dla kółek rolniczych”, drugim - „Gospodarz wiejski”. Oba uzyskały akceptację korespondenta, „Gospodarz” zaś - wręcz pochwałę, że jest „wybornie redagowany”.

\section{Podsumowanie}

Problemy Galicji poruszane na łamach „Kłosów” skupiały się wokół oświaty ludowej, upowszechniania czytelnictwa (rozumianego jako alfabetyzacja) oraz powszechnie znanej galicyjskiej biedy. Stąd wynika nacisk kładziony na stronę ekonomiczną przedsięwzięć wydawniczych - duże zainteresowanie wzbudzały tanie wydania literatury pięknej (inicjatywy K. J. Turowskiego, F. Trzecieskiego). Właściwie każdy problem dotyczący Galicji, poruszany na lamach „Klosów” omawiany byl w aspekcie zacofania umyslowego i gospodarczego w stosunku do pozostałych ziem polskich. Książkom i czasopismom przypisywano przede wszystkim rolę edukacyjną. Pozytywne opinie zbierały głównie wydawnictwa ekonomiczne, zawierające ogólne wnioski oraz praktyczne porady gospodarskie.

\footnotetext{
102 Tamże.

${ }^{103}$ Korespondencya czasopisma Kłosy, „Kłosy”, 50:1890, nr 1291, s. 206.
} 
Ze względu na liberalną wobec Polaków politykę Austro-Wegier, Galicja stała się miejscem rozwoju wydawnictw edukacyjnych i naukowych. Na tym terenie rozwijało się szkolnictwo polskie, więc tu opracowywano i wydawano książki szkolne, zwłaszcza $z$ dziedziny historii i języka polskiego. Rozwijał się ruch ludowy i zwiazana $z$ nim literatura ludowa. Oświatę wśród ludu szerzyli działacze społeczni, posługując się wydawanymi w tym celu drobnymi utworami literackimi oraz poprzez prasę ludową. Oświata wśród ludu prowadzona była również na poziomie Sejmu Krajowego, którego decyzje raczej ją hamowaly. Marazm społeczny wyglądał podobnie jak w Królestwie Polskim, również tu brakowało zainteresowania rozwojem nauki. Ze Lwowa i Krakowa płynęły informacje o obojętności wobec wydarzeń kulturalno - literackich.

Z badań nad książką i księgozbiorami historycznymi, 3:2009 